\title{
Influence of propolis biologically active sub- stances on blood biochemical parameters and morphometric indicators of intestines of store pigs
}

\author{
N.V. Gaponov ${ }^{1,2,{ }^{*}}$ G.L. Yagovenko ${ }^{2}$, A.N. Stepanova ${ }^{3}$, O.P Neverova ${ }^{4}$ and O.V. Gorelik ${ }^{4}$ \\ ${ }^{1}$ FSBI Scientific «Research Institute of Medical Primatology», World st., 177, 354376 Krasnodar Ter- \\ ritory, Sochi, Russia \\ ${ }^{2}$ All-Russian Lupine Scientific Research Institute - Branch of the FSBS Institution «Federal Williams \\ Research Center of Forage Production and Agroecology», 241524 Bryansk region, p/o Michurinskiy, \\ Berezovaya str., 2, Russia \\ ${ }^{3}$ Company "Pedigree trout breeding farm" Adler ", 354393 Krasnodar Territory, Sochi, Adler district, \\ s. Cossack Brod, st. Trout, 45A, Russia \\ ${ }^{4}$ Ural State Agrarian University, 620075 Yekaterinburg, Russia
}

\begin{abstract}
The results of research in some cases allow to judge the change in the functional activity of the studied organs after the use of the preparation. The obtained factual material significantly supplements the information about the biological properties of the propolis water-alcohol emulsion. In practical veterinary medicine, the results of research can be taken into account when prescribing propolis for therapeutic and preventive purposes. Thus, as a result of the study, it was found that the most characteristic histological changes in the structural components of the intestinal wall are observed in the ileum of young pigs and pigs of the experimental groups. The height of this intestine villi in young pigs of the experimental group is $280.97 \pm 3.37$ microns, and in the control group - $193.89 \pm 2.66$ microns $(\mathrm{p}<0.001)$. In pigs treated with the preparation, the villi also have a higher height $-256.89 \pm 1.62$ microns compared to $163.96 \pm 0.61$ microns in the control group. In young pigs and pigs of the control groups, the shape of the ileum villi is finger-shaped or bottle-shaped, and in animals of the experimental groups their forms are more differentiated - bottle-shaped, leafshaped and dome-shaped. This will allow store pigs receiving propolis preparation to better absorb the nutrients of the diet and gain weight faster. The research results are of interest to researchers developing propolis preparations for oral use.
\end{abstract}

\section{Introduction}

Increased interest in propolis in the last 30-40 years is caused by its various biological properties, which are caused by the action of a complex of chemical compounds that make

\footnotetext{
${ }^{*}$ Corresponding author: nv.1000@bk.ru
} 
up its composition $[10,11,12]$. One of the most valuable in terms of practical use is the antimicrobial properties of propolis. In experiments, it was found that water (1:2) and alcohol (1:5) extracts have a bactericidal and bacteriostatic effect, but acetone and alcohol extracts of propolis have a more pronounced bactericidal activity, in solutions of which even spores die in a day. The solvents do not have a sporocidal effect [20, 21, 13, 15].

In veterinary medicine, medicinal products from propolis are used for a number of diseases of farm animals [14].

Healing of wounds and burns in farm animals occurs much faster with the use of $5-10 \%$ propolis ointment on vaseline oil and fish oil $[6,38,39]$.

A good therapeutic effectiveness of $10-15-20 \%$ propolis ointment on vaseline was noted for various wounds, abscesses located in the area of coronary band, joints that are difficult to treat by conventional methods [18].

Propolis ointment was successfully used for keratoconjunctivitis, corneal clouding, wounds with pathological granulations in cattle $[17,35]$ used for the treatment of wounds in farm animals alcohol solution of propolis, it has a noticeable effect on the epithelization of damaged tissue. $[8,9]$.

Propolis ointment is used to treat non-healing umbilical cord in calves. Double smearing with 15 and $20 \%$ propolis ointment of inflammation area of the umbilical ring during the first three days of life protects them from sepsis and death [26, 28].

Propolis preparations are also used in medical practice in the treatment of diseases of the gastrointestinal tract, positive results were obtained. Treatment of pneumonia with propolis [25].

The study of the bactericidal properties of propolis collected in the Kirov region confirms a higher sensitivity of gram-positive saprophytic microflora in comparison with gram-negative and individual (strain) sensitivity to propolis [30, 31].

Propolis samples differ in their antibacterial activity depending on the place of origin. To use propolis as an antimicrobial agent, a mixture of propolis from different zones is recommended, since in this case its bactericidal effect against rabies strains of microorganisms will be stronger [22].

Propolis obtained in the North Caucasus and high-altitude areas of Bulgaria is considered to be the most active antimicrobial agent $[33,34,35]$. Propolis also has a virucidal effect. Studies have found that the high survival rate of mice infected with the flu virus and treated with propolis suggests that propolis is able to induce viral inhibitors, the mechanism of which is similar to interferon [32]. Found an antiviral effect of a combination of royal jelly, propolis and honey against the influenza A2 virus, even in a solution of 1:10. When studying the effect of propolis preparations on the Aujeszky disease virus, it is concluded that propolis preparations in vitro have an inhibitory effect (water-alcohol emulsion at a dose of $15 \mathrm{mg} / \mathrm{ml}$ and water propolis extract at a dose of $6 \mathrm{mg} / \mathrm{ml}$ ).

Found that an aqueous propolis extract with a dry matter content of $25 \mathrm{mg} / \mathrm{ml}$ inactivates the Newcastle disease virus within 2-15 minutes [16].

Along with antibacterial and antiviral properties, propolis has a fungicidal effect.

Propolis has a destructive effect on certain types of pathogenic fungi from the Candida genus, on mold and alcoholic yeast [2], notes that the fungistatic effect of various propolis samples on mold and yeast-like fungi in $80 \%$ of cases was manifested in doses of $6-8 \mathrm{mg} / \mathrm{ml}$.

The antimicrobial activity of propolis has been observed against more than 100 species of bacteria and fungi and is associated not only with its direct effect on pathogens, but also with changes in the immunological reactivity of the macroorganism, since propolis additionally activates specific and non-specific immune factors. The effect of high temperatures does not affect its antimicrobial properties. In some cases, propolis is more active than antibiotics. It has a deleteriolis effect on microorganisms that are resistant to antibiotics, stimulates phagocytosis, reduces the overall resistance of microorganisms. Propolis does not cause resistance 
of microorganisms to itself, does not affect the composition of the intestinal microflora and does not lead to dysbiosis with prolonged use inside [15].

Propolis preparations are used in surgical practice [24]; in oncological diseases [3]; has a favorable effect on radiation reactions; applied in urological practice [5]; gynecology [36]; in endocrine diseases [26]; in skin diseases, tuberculosis [3] and many other diseases.

Propolis in the vaccine induces the synthesis of $\mathrm{C}$ reactive protein in animals. At the same time, the positive reaction on $\mathrm{C}$-reactive protein preceded the activation of neutrophils and the synthesis of salmonela $\mathrm{O}$ - and $\mathrm{N}$ - agglutinins, and propolis stimulates the production of antibodies [30].

There is practically no information in the literature about the morphological reaction of the digestive system under the influence of the preparation. Notes the absence of morphological changes in the stomach and small intestine of animals that took the preparation $[7,9]$. Report the presence of granular inclusions of propolis in the stomach, liver and gall bladder of animals after taking preparations made from native raw materials [31]. The influence of propolis preparations on blood biochemical parameters is relatively poorly covered.

Incomplete and comprehensive information about the biologically active substances of propolis and their influence on the morphology of the gastrointestinal tract of a growing pig body and blood biochemical parameters is the basis for research.

Work objective: To establish the effect of water-alcohol propolis emulsion on the morphology of the gastrointestinal tract (small intestine) and biochemical blood parameters of young pigs at different ages.

\section{Materials and methods of research}

To achieve these objectives, two scientific and economic experiments were carried out with young pigs from 2 months of age (experience 1) and from 4 months of age (experience 2). According to the method of conducting zootechnical experiments [8] two groups of 2-monthold young pigs (nursery) and 2 groups of 4-month-old pigs (initial fattening period) were formed. In each group, the number of animals was 10 heads. Control animals were assigned to the 1st groups, experimental young pigs were assigned to the 2nd groups. Experimental groups of young pigs and pigs were given a water-alcohol propolis emulsion in a dose of 1.5 $\mathrm{ml} / \mathrm{kg}$ of live weight 30 minutes before feeding. [17, 18, 19].

Table 1. Experiment scheme

\begin{tabular}{|c|c|c|c|}
\hline Groups & $\begin{array}{c}\text { Number } \\
\text { of animals }\end{array}$ & Age, month & Feeding conditions \\
\hline \multicolumn{4}{|c|}{ I experience } \\
\hline $\begin{array}{c}\text { I } \\
\text { Control }\end{array}$ & 10 & 2 & Control diet (CD) \\
\hline $\begin{array}{c}\text { II } \\
\text { Experiment }\end{array}$ & 10 & 2 & $\begin{array}{l}\mathrm{CD}+1.5 \mathrm{ml} / \mathrm{kg} \text { of } \\
\text { body weight. water- } \\
\text { alcohol propolis } \\
\text { emulsion }\end{array}$ \\
\hline \multicolumn{4}{|c|}{ II experience } \\
\hline $\begin{array}{c}\text { I } \\
\text { Control } \\
\end{array}$ & 10 & 4 & Control diet (CD) \\
\hline $\begin{array}{c}\text { II } \\
\text { Experiment }\end{array}$ & 10 & 4 & $\begin{array}{l}\mathrm{CD}+1.5 \mathrm{ml} / \mathrm{kg} \text { of } \\
\text { body weight. water- } \\
\text { alcohol propolis } \\
\text { emulsion }\end{array}$ \\
\hline
\end{tabular}


The test preparation was administered according to recommendations. In experiments on young pigs, the water-alcohol emulsion was applied individually according to the assigned numbers, for 60 days, once a day in the morning period of feed distribution.

Propolis, which was the raw material for producing water-alcohol emulsion, was tested for compliance with the quality standard of the RSFSR 317-77 "Propolis" on the recommendation of $[21,22,23]$. For this purpose, we conducted research on the quality of propolis in the Bryansk control and analytical laboratory "Bryansk formation". According to the results of studies of native propolis, it was found that its physical and chemical parameters meet the requirements of the declared standard.

Throughout the experiment, weekly weighing of young pigs, both experimental and control groups, was carried out. During the periods of every 30 days, blood samples were taken in order to control biochemical parameters in its serum - calcium and phosphorus $(\mathrm{mg} \%)$, reserve alkalinity, and total protein in plasma (\%). Laboratory blood tests were also conducted in the regional veterinary laboratory. By the method;

- content of total protein in the blood serum by the refractometric method,

- protein fractions by nephelometric method

- calcium content - Wilkinson complexometric method with murexide,

- phosphorus - photometric with vanadate-molybdenum

After reaching 4 month age in the first experiment, and in the second - 6 months of age of the young pigs, 3 heads were slaughtered in each group. Macromorphometric measurements of the obtained organs were carried out with a caliper, measuring tape and ruler with a division value of $1 \mathrm{~mm}$. Weighing was carried out on a scale with an accuracy of $0.5 \mathrm{~g}$. Segments of $1 \mathrm{x} 1 \mathrm{~cm}$ in size were isolated from tissue and organ sections to obtain histological sections. The selected material was fixed in $10 \%$ neutral formalin. Histo-sections with a thickness of 6 microns were obtained on a freezing microtome, and paraffin sections on a sledge microtome. In the future, sections were stained in hematoxylin-eosin, followed by its conclusion in a balm.

Histometric and cytometric measurements and studies of structural components on their histological sections were performed using light microscopes. Representativeness of the obtained information on histometric measurements of organ structures were carried out by random selection in the field of view of the microscope using a substage. The number of microscopic objects was determined in the microscope field of view. All obtained experimental data was recorded and photographed. Microphotographs from histological sections were obtained using a microscope-spectrophotometer MSFU-K-A4 [1].

The experimental results were mathematically processed and expressed as arithmetic averages and their standard errors. The statistical significance of the differences was determined using a single-factor analysis of variance with subsequent a posteriori adjustments for multiple comparisons using the Tukey and Sidak method. The accepted level of statistical significance is $\mathrm{p}<0.05$.

\section{Results of the study and their discussion}

The results of clinical observations of animals of the first and second experiments showed the absence of diseases and cases of death, both in the control and experimental groups. The biochemical parameters of the blood of all animals in the dynamics of the experiment were within the physiological norm. The exception was only a slight decrease below the norm in young pigs of the control group of the reserve alkalinity of $44.81 \pm 0.98 \mathrm{vol} \% \mathrm{CO}_{2}$, observed at the beginning of the experiment. In young pigs of the experimental group during this period, the average value of this indicator is $51.62 \pm 2.56 \mathrm{vol} \%(\mathrm{p}<0.05)$. Subsequently, in the whole animal, the values of this indicator, as well as the level of calcium, phosphorus and 
total serum protein, fluctuated slightly, without going beyond the permissible physiological norms. There were no significant differences in these indicators in animals of the control and experimental groups.

Table 2. Blood biochemical parameters $(\mathrm{X} \pm \mathrm{Sx})$

\begin{tabular}{|c|c|c|c|c|}
\hline \multirow[t]{2}{*}{ Indicators } & \multicolumn{2}{|c|}{ Age 2-4 months } & \multicolumn{2}{|c|}{ Age $4-6$ months } \\
\hline & Control & Experiment & Control & Experiment \\
\hline $\begin{array}{l}\text { Calcium, } \mathrm{mg} \% \text { : } \\
1 \text { - at the beginning of } \\
\text { the experiment } \\
2 \text { - after } 30 \text { days } \\
3 \text { - after } 60 \text { days }\end{array}$ & $\begin{array}{l}10.42 \pm 0.19 \\
10.97 \pm 0.60 \\
10.81 \pm 0.40\end{array}$ & $\begin{array}{r}10.76 \pm 0.26 \\
12.14 \pm 0.91 \\
12.32 \pm 0.62\end{array}$ & $\begin{array}{l}10.29 \pm 0.25 \\
10.29 \pm 0.25 \\
11.11 \pm 0.38\end{array}$ & $\begin{array}{l}10.25 \pm 0.16 \\
10.35 \pm 0.16 \\
11.11 \pm 0.31\end{array}$ \\
\hline $\begin{array}{l}\text { Phosphorus, } \mathrm{mg} \% \text {; } \\
1 \text { - at the beginning of } \\
\text { the experiment } \\
2 \text { - after } 30 \text { days } \\
3 \text { - after } 60 \text { days }\end{array}$ & $\begin{array}{l}5.03 \pm 0.23 \\
4.99 \pm 0.26 \\
5.43 \pm 0.21\end{array}$ & $\begin{array}{l}5.32 \pm 0.11 \\
5.31 \pm 0.20 \\
5.08 \pm 0.21\end{array}$ & $\begin{array}{l}4.55 \pm 0.22 \\
4.94 \pm 0.20 \\
5.31 \pm 0.22\end{array}$ & $\begin{array}{l}4.60 \pm 0.21 \\
5.11 \pm 0.22 \\
5.23 \pm 0.09\end{array}$ \\
\hline $\begin{array}{l}\text { Reserve alkalinity, vol. } \\
\% \mathrm{CO}_{2} \text { : } \\
1 \text { - at the beginning of } \\
\text { the experiment } \\
2 \text { - after } 30 \text { days } \\
3 \text { - after } 60 \text { days }\end{array}$ & $\begin{array}{l}44.81 \pm 0.99 \\
48.73 \pm 0.81 \\
46.26 \pm 1.13\end{array}$ & $\begin{array}{c}51.62 \pm 2.56^{*} \\
50.91 \pm 1.68 \\
45.82 \pm 0.87\end{array}$ & $\begin{array}{l}45.36 \pm 0.78 \\
47.14 \pm 0.68 \\
46.46 \pm 0.51\end{array}$ & $\begin{array}{l}45.67 \pm 0.49 \\
46.26 \pm 0.91 \\
46.90 \pm 0.35\end{array}$ \\
\hline $\begin{array}{l}\text { Total protein, \%: } \\
1 \text { - at the beginning of } \\
\text { the experiment } \\
2 \text { - after } 30 \text { days } \\
3 \text { - after } 60 \text { days }\end{array}$ & $\begin{array}{l}7.50 \pm 0.15 \\
7.46 \pm 0.12 \\
7.86 \pm 0.25\end{array}$ & $\begin{array}{c}7.17 \pm 0.11 \\
7.70 \pm 0.12 * * \\
7.67 \pm 0.23\end{array}$ & $\begin{array}{l}7.34 \pm 0.19 \\
7.52 \pm 0.27 \\
7.65 \pm 0.22\end{array}$ & $\begin{array}{l}7.68 \pm 0.19 \\
7.64 \pm 0.16 \\
7.62 \pm 0.19\end{array}$ \\
\hline
\end{tabular}

Note: ${ }^{*} \mathrm{p}<0.05, * * \mathrm{p}<0.01$

This result is consistent with the results of [20,30,37], who conducted similar studies on the use of the preparation in raising young pigs, as well as with the work of.

In order to establish the effect of water-alcohol emulsion on the morphological structure of the small intestine wall of the experimental groups of the 1st and 2nd experiments, organometric and histometric studies of each intestine included in the segment were performed. The studied organometric parameters included the length and diameter of individual intestines, and the percentage of each of them to the total length of the small intestine. In store pigs treated with the preparation, the length of the small intestine is longer than in analogues.

Table 3. Morphometric parameters of the small intestine $(\mathrm{X} \pm \mathrm{Sx})$

\begin{tabular}{|l|c|c|c|c|}
\hline \multirow{2}{*}{ Indicators } & \multicolumn{2}{|c|}{ Age 2-4 months } & \multicolumn{2}{c|}{ Age 4-6 months } \\
\cline { 2 - 5 } & Control & Experiment & Control & Experiment \\
\hline Small intestine & & & & $2826.67 \pm$ \\
length, cm & $2366.67 \pm 29.63$ & $2416.67 \pm 31.80$ & $2643.67 \pm 13.20$ & $20.28^{* *}$ \\
\hline $\begin{array}{l}\text { Duodenum: } \\
\text { Length, cm }\end{array}$ & & & & \\
Diameter, mm & $553.33 \pm 8.82$ & $596.67 \pm 18.82^{*}$ & $853.33 \pm 34.04$ & $883.33 \pm 18.82$ \\
& $33.33 \pm 2.4$ & $27.66 \pm 8.88$ & $38.67 \pm 2.03$ & $32.33 \pm 0.88^{*}$ \\
\hline $\begin{array}{l}\text { From the small } \\
\text { intestine length, }\end{array}$ & $23.39 \pm 0.66$ & $24.68 \pm 0.05$ & $32.27 \pm 0.74$ & $31.25 \pm 0.10$ \\
$\%$ & & & & \\
\hline
\end{tabular}




\begin{tabular}{|c|c|c|c|c|}
\hline $\begin{array}{l}\text { Jejunum: } \\
\text { Length, } \mathrm{cm} \\
\text { Diameter, } \mathrm{mm}\end{array}$ & $\begin{array}{c}1623.33 \pm 32.83 \\
25.83 \pm 0.17\end{array}$ & $\begin{array}{c}1656.67 \pm 17.64 \\
29.50 \pm 0.76^{*}\end{array}$ & $\begin{array}{c}1646.67 \pm 14.53 \\
32.00 \pm 1.15\end{array}$ & $\begin{array}{c}1726.67 \pm 18.56^{*} \\
34.67 \pm 0.88\end{array}$ \\
\hline $\begin{array}{l}\text { From the small } \\
\text { intestine length, } \\
\%\end{array}$ & $68.58 \pm 0.52$ & $68.56 \pm 10.25$ & $62.29 \pm 0.83$ & $61.08 \pm 0.26$ \\
\hline $\begin{array}{l}\text { Ileum: Length, } \\
\mathrm{cm} \\
\text { Diameter, } \mathrm{mm}\end{array}$ & $\begin{array}{c}190 \pm 5.77 \\
27.67 \pm 0.88\end{array}$ & $\begin{array}{c}163.33 \pm 6.67^{* *} \\
23.00 \pm 0.58^{* *}\end{array}$ & $\begin{array}{c}143.67 \pm 3.28 \\
22.00 \pm 0.58\end{array}$ & $\begin{array}{c}213.33 \pm 8.82 * * \\
20.50 \pm 0.29\end{array}$ \\
\hline $\begin{array}{l}\text { From the small } \\
\text { intestine length, } \\
\%\end{array}$ & $8.02 \pm 0.15$ & $6.75 \pm 0.20 *$ & $5.43 \pm 0.1$ & $7.55 \pm 0.36^{* *}$ \\
\hline
\end{tabular}

Note: ${ }^{*} \mathrm{p}<0.05, * * \mathrm{p}<0.01$

So, in young pigs of the experimental group, it is $2416.67 \pm 31.80 \mathrm{~mm}$, and in the control group it is $2366.67 \pm 29.63 \mathrm{~mm}$. However, the differences are statistically unreliable. At the same time, in pigs of the experimental group, a significant increase in the small intestine was found $-2826.67 \pm 20.28 \mathrm{~mm}$ and $2643.67 \pm 13.20 \mathrm{~mm}$ in analogues with a probability ( $\mathrm{p}<$ 0.01 ). The duodenum of the experimental groups is longer than their analogues and corresponds to $596.6 \pm 8.82 \mathrm{~mm}$, in young pigs of the experimental group and $553.33 \pm 8.82 \mathrm{~mm}$ in their analogues with a probability $(\mathrm{p}<0.05)$ and in pigs $883.33 \pm 88 \mathrm{~mm}$ and $853.33 \pm$ $24.04 \mathrm{~mm}$, respectively. In experimental animals, the diameter of the intestine is smaller. In young pigs of the experimental group it is of $27.66 \pm 8,88 \mathrm{~mm}$ vs $33,33 \pm 2.40 \mathrm{~mm}$ on the control, and in pigs $-32,33 \pm 0,88 \mathrm{~mm}$ and of $38.67 \pm 2.03 \mathrm{~mm}$, respectively $(\mathrm{p}<0.05)$. In the ratio of the length of the duodenum to the length of the small intestine in animals of the compared groups, no significant differences were established. In young pigs of the experimental group, the indicator was $24.68 \pm 0.06 \%$, and in the control group $-23.39 \pm 0.67 \%$. In pigs of the experimental group, $31.25 \pm 0.11 \%$ and $32.27 \pm 0.75 \%$, respectively. The length of the jejunum in animals receiving the preparation is higher than the control values and is $1656.67 \pm 17.67 \mathrm{~mm}$ in young pigs and $1726.67 \pm 18.56 \mathrm{~mm}(\mathrm{p}<0.05)$ in pigs of the experimental groups versus $1623.33 \pm 32,83 \mathrm{~mm}$ in piglets and $1646.67 \pm 14.53 \mathrm{~mm}$ in pigs of control groups. The diameter of the jejunum in animals receiving the propolis preparation is also greater than the control values and is $29.50 \pm 0.76 \mathrm{~mm}(\mathrm{p}<0.05)$ in piglets and $34.67 \pm$ $0.88 \mathrm{~mm}$ in pigs of the experimental group versus $25.83 \pm 0.17 \mathrm{~mm}$ in young pigs and $32 \pm$ $1.15 \mathrm{~mm}$ in pigs in control groups. According to the ratio of the length of the jejunum to the length of the small intestine, as the duodenum, no statistically significant differences in the animals of the comparison groups. In young pigs of the experimental group the indicator is $68,56 \pm 0.26 \%$ and in the control group $68,58 \pm 0,53 \%$ in pigs $-61,08 \pm 0.27 \%$ and $62,29 \pm$ $0,84 \%$, respectively. Changes in the length of the ileum under the influence of the preparation have an uneven character in young pigs and pigs of the experimental groups. For example, in young pigs of the experimental group, the length of the intestine is slightly shorter than in the control group $-163.33 \pm 6.67 \mathrm{~mm}$ versus $190 \pm 5.77 \mathrm{~mm}(\mathrm{p}<0.05)$. In pigs of the experimental group, on the contrary, the ileum is significantly longer $-213.33 \pm 8.82 \mathrm{~mm}$ than in the control group - $143.67 \pm 3.28 \mathrm{~mm}(\mathrm{p}<0,01)$. The diameter of the ileum in animals treated with the preparation is slightly smaller. In young pigs of the experimental group, it is $23 \pm$ $0.58 \mathrm{~mm}$, and in the control group, $27.67 \pm 0.88 \mathrm{~mm}(\mathrm{p}<0.05)$. In pigs of the experimental group, the gut diameter is $20.5 \pm 0.29 \mathrm{~mm}$, and in the control group $-22 \pm 0.58 \mathrm{~mm}$. The most prominent changes were found in the study of the percentage ratio of the length of the ileum to the total length of the small intestine. In young pigs of the experimental group, the intestinal length is $6.75 \pm 0.2 \%$, and in the control group- $8.02 \pm 0.15 \%$ of the intestinal length. Differences are significant for $\mathrm{p}<0.01$. In pigs of the experimental group, the length of this intestine in percentage terms makes up a larger part of the intestine than in the control -7.55 
$\pm 0.36 \%$ versus $5.43 \pm 0.1 \%$ ( $<<0.05)$; and in pigs of the experimental group, on the contrary, it is significantly lower than the control values and is $134.11 \pm 7.26 \mu \mathrm{m}$ and $189.79 \pm 0.4 \mu \mathrm{m}$, respectively $(\mathrm{p}<0.01)$.

Histological analysis of intestinal sections revealed no destructive or pathological changes in all compared populations.

Histometry of the jejunum wall revealed non-uniformity of changes in the transport-suction drug of the intestinal villi in young pigs and pigs treated with the preparation. The shape of the villi of the jejunum in all animals differs slightly, which is consistent with the data (Svechina K.B. et al., 1967) [29]. In the age-related morphology of the intestine, the villi are mostly elongated, finger-shaped. In pigs of the experimental group cone-shaped and rollershaped forms are observed.

\section{Conclusion}

Thus, research proves that the use of propolis alcohol preparation, in the amount of $1.5 \mathrm{ml} / \mathrm{kg}$ of body weight, once a day with the main diet of feeding young pigs from 2 to 4 months and from 4 to 6 months of age, affects the morphological structure of the digestive system and does not lead to deviations from the physiological norm in the biochemical parameters of blood. As evidenced by the data obtained during the experiment.

\section{References}

1. G.G. Avtandilov. Medical morphometry, (Moscow: Medicine, 1990)

2. A.A. Barskov. Development of standard dosage forms of propolis, evaluation of their antimicrobial and immunostimulating effects in the treatment of farm animals, (Thesis, Doctor of Veterinary Sciences, Kazan, 1988)

3. V.F. Bolshakova. Application of propolis in dermatology, Biological resources of beekeeping and their rational use in national economy and medicine, (Inter-University collection Gorki, 1988)

4. V.F. Bolshakova, B.S. Tikhonov. Gorky SRI of dermatology and venereology, 23, 193196 (1962)

5. V.V. Vasiliev, I.I. Gubanov. On the use of propolis in urological practice, Topical issues of urology, (Kemerovo, 1973)

6. G.N. Vasin. Sc. Notes, Kazan State University, 86, 213-221 (1962)

7. T.V. Vakhonina, Bee pharmacy. 2nd ed., reprint, (St. Petersburg: Lenizdat, 1995)

8. P.I Viktorov, V.K. Menkin. Methodology and organization of the zootechnical experiment. (Moscow: Agropromizdat, 1991)

9. L. Gamko, G. Nuriev, E. Efimenko, N. Gaponov. Pig Breeding, 1, 14-15 (2003)

10. L.N. Gamko, V.E. Sobolev, N.V. Gaponov, Influence of water-alcohol emulsion of propolis on productivity and biochemical parameters of young pigs blood, Materials of the International Scientific and Practical Conference "Young scientists for the revival of agriculture in Russia in the XXI century", (Bryansk, 2000)

11. N.V. Gaponov. Metabolism and energy exchange in young pigs when water-alcohol propolis emulsion is included in their diets under different environmental conditions, Thesis. Cand. Biol. Sc, (Orel, 2002)

12. N.V. Gaponov, L.N. Gamko, V.E. Sobolev. Water-alcohol emulsion of propolis as a stimulator of productivity of young pigs on fattening, Scientific and applied aspects of 
the state and prospects of development of animal husbandry and veterinary medicine, (Abstracts of reports at the International Scientific and Practical conference, 2001)

13. N.V. Gaponov. Adaptive feed production, 2, 114-120 (2020)

14. N.V. Gaponov, Kombikorma, 6, 40-42 (2019)

15. A. Grechanu, V. Iencu. Antibiotic effect of propolis, pollen and honey, Bee products food, health, beauty, (Bucharest: Apimondia, 1985)

16. G.P. Demakov, I.I. Teterev. Tr. inst., Kirovsky ACI, 61, 7-11 (1978)

17. M.M. Dzhambulatov, A.R. Osmanov. Methodological development on the use of propolis in veterinary practice, (Makhachkala: Dagestani ACI, 1975)

18. I.F. Kazakov. Sc. Notes, Kazan State Cet. In. 86, 201-211 (1962)

19. A.P. Kalashnikov, N.N. Kleymenov, V.N. Bakanov, etc. Norms and rations for farm animals feeding: reference guide, (Moscow: Agropromizdat, 2001)

20. Z.Kh.Karimova, T.V. Raspopova, L.S. Afonskaya, et al. Antimicrobial and pharmacological characteristics of some propolis preparations, Mat. rep. All-Union Scientific Conf. ded. to the 90-th anniversary of Kazan Vet, (In. - Kazan, 1963)

21. V.P. Kivalkina. Propolis, its antimicrobial and medicinal properties: Thesis. doctor of Biol. Sciences, (Kazan, 1964)

22. V.P. Kivalina. Scientific notes, Kazan State Vet. In, 7(4),135-141 (1959)

23. V.P. Kivalina, A.A. Barskov, M.G. Mirolyubov et al. Guidelines for the use of propolis in veterinary medicine: Recom, (MDV ACM USSR 14.4.78. M., 1978)

24. V.A. Kupriyanov, L.S. Taits. Experience of using propolis ointment in the treatment of burns and purulent wounds, Biological resources of beekeeping and their rational use in national economy and medicine: Inter-University collection, (Gorky, 1988)

25. E.A. Ludyansky. Beekeeping, 10, 47-48 (1991)

26. N.N. Mikheylesku. Apitherapy for prostate diseases, Bee products food, health, beauty. (Bucharest: Apimondia, 1985)

27. N.A. Peresadin, T.V. Dyachenko. Beekeeping, 3, 57 (1996)

28. S.G. Pokrovsky. Sc. Notes, Kazan State Vet. In., 84, 109-113 (1962)

29. K.B. Svechin, I.A. Arshavsky, A.V. Kvasnitsky, V.N. Nikitin, B.G. Novikov, E.M. Fediy. Age physiology of animals, (M.: Kolos, 1967)

30. I.I. Teterev. Bactericidal properties of propolis collected in the Kirov region, Tr. of the In., (Kirovsky ACI., 1976)

31. A.I. Tikhonov, S.V. Yavtushenko. Beekeeping, 9, 28-29 1984

32. B.L. Filipich, M. Ikar. Therapeutic value of royal jelly and propolis in viral diseases. Bee products-food, health, beauty, (Bucharest: Apimondia, 1985)

33. P.I. Fillipov, A.G. Butov. Nature's gift is priceless: honey and other bee products in nutrition and medicine, (Stavropol: Stavropol publishing house, 1991)

34. V.M. Frolov, N.A. Peresadin. Beekeeping, 4, 53-54 (1994)

35. I. Shutta, I. Hanko, I. Yanda, Tkach. Experimental and clinical results of treatment of wounds in farm animals, local application of alcohol propolis solution, Valuable product of beekeeping: propolis, (Bucharest: Apimondia, 1975)

36. M. Yalomitsyanu, N. Nicolaou, V. Dagis. Prospects for the use of propolis in diseases caused by flagellates and fungi, Bee products food, health, beauty, (Bucharest: Apimondia, 1985) 
37. N.V. Gaponov, S.V. Svistunov, N.N. Bondarenko, I.A. Romanenko. Bulletin the National academy of sciences of the Republic of Kazakhstan, 2(384), 22 - 28, (2020)

38. N.V. Gaponov, G.L. Yagovenko, E3S Web of Conferences, 176, 01002 (2020)

39. N.V. Gaponov, O.P. Neverova, O.V. Gorelik, S.Y. Kharlap, T.I. Bezhinar. E3S Web of Conferences, 176, 01004, (2020) 